\section{AL-AZHAR Dental Journal}

F o r

G i r
The Official Publication of The Faculty of Dental Medicine For Girls, Al-Azhar University Cairo, Egypt.

Print ISSN 2537-0308 • Online ISSN 2537-0316

ADJ-for Girls, Vol. 8, No. 2, April (2021) — PP. 301:305

\title{
Evaluation of Antibacterial Properties of Chitosan Modified Glass Ionomer on Streptococcus Mutans in Comparison with the Conventional Glass Ionomer
}

\section{Eman I. Abd El-Maksoud ${ }^{1 *}$, Mohamed H. Mostafa ${ }^{2}$, Magda A. Elmalt ${ }^{3}$, Salam M. Elaraby ${ }^{4}$}

Codex : 01/21.04

azhardentj@azhar.edu.eg

http://adjg.journals.ekb.eg

DOI: $10.21608 /$ adjg.2021.14103.1172

Pediatric Dentistry \& Orthodontics ( Pediatric Dentistry, Orthodontics)

\begin{abstract}
Purpose: To evaluate the antibacterial characters of Glass Ionomer modified with $\mathrm{CH}$ on Streptococcus Mutans in Comparison With the original glass ionomer. Materials and methods: caries removal of 30 extracted primary molars, these teeth divided into three groups the first group restored with chitosan modified glass ionomer and second one restored with conventional glass ionomer and the third group restored with glacial acetic acid modified glass ionomer then sterilized at oven $60 \mathrm{c}$ for 72 hours Each group was placed in mitis salivarius media with well-defined number of bacteria of streptococcus mutans, then left them for 48 hours , after 48 hours solution of each group was taken and was placed in mitis salivarius plate for another 48 hours and then bacterial counting was made to see if number of bacteria increased or decreased. Results: The Chitosan modified glass ionomer had higher antimicrobial effect than conventional glass ionomer and glass ionomer modified with glacial. Statistical analysis between the groups revealed that actually a statistically considerable difference between the all groups $(P$-value $<0.0001)$. Conclusion: Chitosan can be used as a natural material for modification of glass ionomer to increase the antibacterial effect against streptcoccus mutans and also should be supported by in vivo studies.
\end{abstract}

\section{INTRODUCTION}

Glass ionomer restorations in restorative dentistry made by the base acid reaction between: poly-acrylic acid with powder: Ca-fluoro-alu-
Sreptcoccus Mutans,

Chitosan, Glass Ionomer.

- Paper extracted from Master Thesis Titled" Evaluation of antibacterial properties of Chitosan Modified Glass Ionomer on StreptococcusMutans in Comparison with the Conventional glass ionomer."

1. Demonstrator of Pedodontics and Oral Health, Faculty of Dental Medicine, modern University for Technology and information.

2. Assistant Professor and head of pedodontics and Oral Health, Faculty of Dental Medicine, for Girls, Al Azhar University.

3. Assistant Professor of Pedodontics and Oral Health, Faculty of Dental Medicine, for Girls, Al Azhar University.

4. Lecturer of Pedodontics and Oral Health, Faculty of Dental Medicine, for Girls, Al Azhar University.

* Corresponding author email: emanomarym2009@gmail.com 
mino-silicate glass. Glass ionomers have specific characters for example chemical bond to teeth, it works against bacteria because of flouride. But, this type of restorations have some drawbacks such as brittleness, sensitive to moisture, and weak effect with other materials for restoration ${ }^{(1-3)}$.

Many amendments were formed to the main Glass ionomers to reinforce the antibacterial properties of Glass ionomers because of their low $\mathrm{pH}$ in setting and to the liberation of $\mathrm{F}^{+}$ions. So, The main Glass ionomers is not sufficient against bacteria to stop the cell activity, adherence and film consistence of S.mutans ${ }^{(4-7)}$.

Several studies were formed for improving the effect of Glass ionomers against bacteria without compromising their strength and physical properties .Chitosan is formed of bio-polyaminosaccharide resulted from chitin deacetylation, having special characteristics for example mucoadhesion, degradable and compatible. Researches showed that mechanical strength of conventional GICs could be enhanced considerably by adding a $10 \% \mathrm{v} / \mathrm{v}$ of Chitosan along with an increase in fluoride release and antibacterial properties ${ }^{(8-12)}$.

Due to a positive charge, chitosan adheres to the bacterial cell wall and cell membrane and can have both bacteriostatic and bactericidal effects. Most strength of this restoration is on $\mathrm{Gm}+\mathrm{ve}$ microbiota, for example S. mutans, S.sanguis Streptococcus mitus, S. salivarius, and yeasts. $\mathrm{CH}$ is a weak base and is not dissolve with $\mathrm{H}_{2} \mathrm{O}$ and organic solvents but it dissolves in dilute aqueous acidic solutions for example acetic acid. Also, it has specific properties like biodegradable, mucoadhesion, biocompatible and have increase effect against bacteria and biofilm characters against different types of bacteria .Chitosan was inspected, before, in dental field related to antibacterial effects which attack Streptococcus mutans which have predicting findings ${ }^{(13-20)}$

\section{MATERIALS AND METHODS}

\section{Preparation of teeth:}

a. Surface disinfection: the teeth were disinfected with $1 \% \mathrm{NaOCl}$.

b. Cleaning: The teeth were cleaned from outside to remove any tissue debris by tooth brush, then washed with water and stored in thymol solution until their use.

\section{Teeth Sterilization:}

In oven $60 \mathrm{C}$ for 72 hours ( 3 days)

\section{Grouping of the samples:}

The specimens were sectioned to three groups:

$1^{\text {st }}$ Group: include 10 samples in which they were restored with chitosan modified glass ionomer to show the antibacterial effect on streptcocuss mutans.

$2^{\text {nd }}$ Group: include 10 samples in which they were restored with conventional glass ionomer

$3^{\text {rd }}$ Group: include 10 samples in which they were restored wilth glascial acid modified glass ionomer

\section{Preparation of culture media:}

Culture media used in this present study was:

Mitis salivarius agar media.

Culture media were prepared as described by manufacturer, sterilized by autoclaving at $121 \mathrm{c}$ for 15 minutes at $15 \mathrm{psi}$ and stored at $40 \mathrm{c}$ until used.

\section{Preparation of Chitosan}

By using glacial acetic acid, distilled water and chitosan powder as following:

$20 \mathrm{mg}$ of Chitosan was supplied in the form of powder to be mixed with $1.8 \mathrm{ml}$ of glacial acetic acid and completed till $100 \mathrm{ml}$ with pillory water in $100 \mathrm{ml}$ measured flask . 
$1 \mathrm{ml}$ of chitosan solution was added to $9 \mathrm{ml}$ of GIC liquid to obtain $10 \%$ of Chitosan modified glass ionomer .

Each restored tooth was placed in liquid medium which contained well defined number of bacteria $10^{\times 8}$ for 48 hours .

The restored tooth was removed from the liquid medium then the liquid medium which contain bacteria was placed in another plate containing mitis salivarius media for another 48 hours and then bacterial count was made to see the number of bacteria decrease with which group .

\section{Statistical analysis} Statistical analysis was made utilizing a followed with conventional then control commercially available software program (SPSS 19; SPSS, Chicago, IL, USA) to compare between groups and subgroups.

Since values were normally distributed (parametric), comparisons were made utilizing one way analysis of variance (ANOVA), then Tukey's post hoc test for pairwise comparisons when ANOVA revealed a significant difference. Independent $t$ test was used for 2 group comparisons. Degree of significance was set at $\mathrm{P}<0.05$.

\section{RESULTS}

Chitosan modified glass ionomer showed the highest value in reduction of Streptococcus mutants

Table (1) Comparison of Colony forming unit of Streptococcus mutants $\left(x 10^{3}\right)$ in all groups (ANOVA test)

\begin{tabular}{|c|c|c|c|c|c|c|c|}
\hline \multirow{2}{*}{ Groups } & \multirow[b]{2}{*}{ Mean } & \multirow[b]{2}{*}{ Std. Dev } & \multirow[b]{2}{*}{ Std. Error } & \multicolumn{2}{|c|}{$\begin{array}{l}\text { 95\% Confidence } \\
\text { Interval for Mean }\end{array}$} & \multirow[b]{2}{*}{ Min } & \multirow[b]{2}{*}{ Max } \\
\hline & & & & $\begin{array}{l}\text { Lower } \\
\text { Bound }\end{array}$ & $\begin{array}{l}\text { Upper } \\
\text { Bound }\end{array}$ & & \\
\hline -Conventional glass ionomer & $41.7^{b}$ & 14.1 & 12.7 & 4.6 & 88.0 & .4 & 450.0 \\
\hline -Chitosan modified glass ionomer & $.11^{\mathrm{c}}$ & .08 & .02 & .08 & .14 & .02 & .29 \\
\hline -Control & $815000^{\mathrm{a}}$ & 8366.6 & 3415.7 & 806219.8 & 823780.2 & 810000 & 830000 \\
\hline $\mathbf{F}$ & & & & 325642.0 & & & \\
\hline $\mathbf{P}$ & & & & $<0.0001 *$ & & & \\
\hline
\end{tabular}

-Significance level $P<0.05$

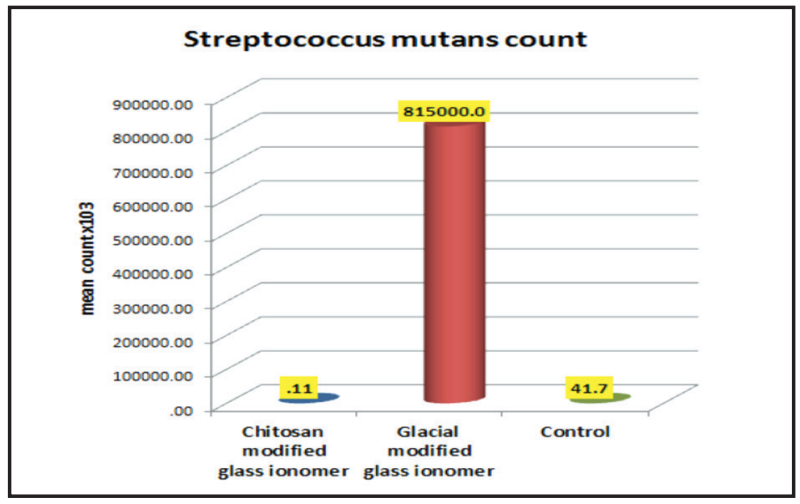

Figure (1): Shows Column chart showing mean value of Colony forming unit of Streptococcus mutants $\left(\times 10^{3}\right)$ in all groups.

\section{DISCUSSION}

S. mutans is the main reason of the caries disease and infective endocarditis. Primary causes accompanied with caries formation is acid tolerance, adhesion and acidogenicity. All of these properties put in together to change the properties of dental plaque. Properties alteration are distinguished by increased number of Streptococcus mutans and other types are identical in aciduric bacteria and acidogenic bacteria. This survey based on the properties of bacteria that participate in each 
virulence components. Formation of dental decay supported by series of the Streptococcus mutans gene and experiment shapes which represented by plaque biofilm of Streptococcus mutans which responsible for dental caries. In addition to acid formation by $\mathrm{S}$. mutans it has an aciduric property as it preserves glycolytic abilities at which growth are inhibitory (is low $\mathrm{pH} 4.4$ ). In this study S. mutans was chosen for investigation because $\mathrm{S}$. mutans was established in higher percentage in dental plaque ${ }^{(21-23)}$.

This choice of bacteria was in accordance with other previous studies that used S. mutans. This is because S.mutans possess some virulent factors such as acidogenicity as S. mutans can form lactate, formate, acetate, and ethanol as a fermentation results and aciduricity. S. mutans preserve glycolytic capabilities at low $\mathrm{pH}$. Where other studies used staph- aureus because of the existence of S. aureus found in caries formation development, spread and chitosan modified glass ionomer increase zone of inhibition than conventional one. Other studies used lactobacillus because it's the most resistant oral microorganism to inhibitory effect of $\mathrm{GI}^{(14,22,24,25,26,27)}$.

In the current study bacterial counting technique was utilized for knowing an antibacterial efficacy of CH-GI by counting the number of S. mutans on media plates showing reduction of the number of bacteria. Other studies used zone of inhibition to determine the antibacterial efficacy of $\mathrm{CH}$-GIC because they make circular discs of restorations. In the present study modification of GI was done using a natural material which is $\mathrm{CH}$ because of its antibacterial activity to be compared with conventional one. $\mathrm{CH}$ is a natural antibacterial product for modifying GIs . For creating a GIs restoration with important anti-bacterial effect, mostly it relay on the quantity and type of antimicrobial agent added to GIs, modifying GIs with various antimicrobial product without making any side effects on the other physical and bonding properties . By adding $\mathrm{CH}$ in the polycarboxylic acid of GIC at $\mathrm{v} / \mathrm{v}$ ratios of ten percent increase its effect against bacteria than conventional Glass ionomer against SM. ${ }^{(11,14,21,28,29,30)}$.

\section{CONCLUSION}

Under the condition of this study we concluded that:

By adding $10 \% \mathrm{v} / \mathrm{v}$ of Chitosan into polyacrylic acid of GIC showed a significant increase in antibacterial effect than conventional one against streptcoccus mutans. So $10 \%$ of $\mathrm{CH}$ can be used as natural alternative modification in Glass ionomer restorations because of its antibacterial effect against streptococcus mutans. This method could be an effective line for S.Mutans reduction in primary restorative tooth and needed to be confirmed clinically due to presence of other different microrganism and other conditions like $\mathrm{pH}$, solubility of GIC,liquids.

\section{RECOMMENDATIONS}

1. This in vitro study of the antibacterial effect of Chitosan modified glass ionomer should be supported by in vivo studies.

2. The effect of CH_GIC on other types of bacteria such as lactobacillus because it's the most resistant microorganism to inhibitory effect of GIC.

3. The effect of chitosan with different concentration that may give higher antimicrobial effect.

\section{Declaration}

No fund was received for this study, and there was no conflict of interest.

\section{REFERENCES}

1. Craig RG, Powers JM and Wataha JC. Dental materials: Properties and manipulation, 8th ed.St. Louis: Mosby,2004.

2. Wilson $\mathrm{AD}$ and McLean JW. Glass-ionomer cement, 2nded. Chicago: Quintessence Publishing Company, 1988.

3. Nicholson JW. Chemistry of glass-ionomer cement: A review. Biomaterials 1998; 19: 485-94. 
4. DeSchepper EJ, White RR and von der Lehr W: Antimicrobial effects of glass ionomers. Am J Dent 1989; 2: $51-6$.

5. Vermeersch G, Leloup G, Delmee M, et al. Antibacterial activity of glass-ionomer cements, compomers and resin composites: Relationship between acidity and material setting phase. J Oral Rehab 2005; 32: 368-74.

6. Eick S, Glockmann E, Brandl B, et al. Adherence of Streptococcus mutans to various restorative materials in a continuous flow system. J Oral Rehab 2004; 31:278-85.

7. Mukai Y and Ten Cate JM. Fluoride, remineralization of advanced root dentin lesions in vitro. Caries Res 2002; 36:275-80

8. Botelho MG. Inhibitory effects on selected oral bacteria of antibacterial agents incorporated in a glass ionomer cement. Caries Res 2003;37:108-14.

9. Botelho MG. The antimicrobial activity of a dentin conditioner combined with antibacterial agents. Oper Dent 2005;30:75-82.

10. Takahashi Y, Imazato S, Kaneshiro AV, Ebisu S, Frencken JE, Tay FR. Antibacterial effects and physical properties of glass-ionomer cements containing chlorhexidine for the ART approach. Dent Mater 2006;22:647-52.

11. Petri DF, Donegá J, Benassi AM, Bocangel JA. Preliminary study on chitosan modified glass ionomer cement. Dent Mater 2006;22:647-52.

12. Ibrahim MA, Neo J, Esguerra RJ, Fawzy AS. Characterization of antibacterial and adhesion properties of chitosan-modified glass ionomer cement. J Biomater Appl 2015;30:409-1.

13. Sanders BJ, Gregory RL, Moore K, Avery DR. Antibacterial and physical properties of resin modified glass-ionomers combined with chlorhexidine. J Oral Rehabil 2002;29:553-8

14. Hoszek A, Ericson D.In vitro fluoride release and the antibacterial effect of glass ionomers containing chlorhexidine gluconate. Oper Dent 2008;33:696-701

15. Muzzarelli RAA. Chitin. New York: Pergamon Press, 1977.

16. Roberts GAF. Chitin chemistry. Houndmills: MacMillan Press, 1992.

17. Hu Y, Yang J, Tang Y, et al. Self-aggregation and antibacterial activity of N-acylated chitosan. Polymer 2007; 48: 3098-106.
18. Xia W, Liu P, Zhang J, et al. Biological activities of chitosan and chitooligosaccharides. Food Hydrocoll 2011; 25: 170-9.

19. Tarsi R, Muzzarelli RA, Guzman CA, et al. Inhibition of Streptococcus mutans adsorption to hydroxyapatite by low-molecular-weight chitosans. Oral Microbiol Immunol 1997; 72: 665-72.

20. Tarsi R, Corbin B, Pruzzo C, et al. Effect of low-molecular- weight chitosans on the adhesive properties of oral streptococci. Oral Microbiol Immunol 1998; 13: 217-24.

21. Fitzgerald, R.J., \& P.H. Keyes: Demonstration of the etiologic role of streptococci in experimental caries in hamsters. J Am. Dent Assoc 1960;61: 9-1

22. Bender, G.R., E.A. Thibodeau, \& R.E. Marquis: Reduction of acidurance of streptococcal growth and glycolysis by fluoride and gramicidin. J Dent Res 1985;64: 90- 5

23. Frostell, G., P. H. Keyes, and R. H. Larson. 1967. Effect of various sugar and sugar substitutes on dental caries in hamsters and rats. J. Nutr. 1967;93:65-76.

24. Petri D, Donega J, Benassi AM, Bocangel JA. Preliminary study on chitosan modified glass ionomer restoratives. J of Dent Mater. 2007;23:1004-10.

25. Perchyonok VT, Reher V, Zhang S, Grobler SR, Basson $\mathrm{N}$. Evaluation of nystatin containing chitosan hydrogels as potential dual action bio-active restorative materials: In Vitro approach. J Funct Biomater 2014;5: 259-72.

26. Herrera M, Castillo A, Baca P, Carrión P. Antibacterial activity of glass-ionomer restorative cements exposed to cavity-producing microorganisms. Oper Dent 1999; 24:286-91

27. Ajdic D, McShan WM, McLaughlin RE, Savic G, Chang J, Carson MB , et al . Genome sequence of Streptococcus mutans UA159, a cariogenic dental pathogen. J. of Proc Natl Acad Sci 2002; 99: 14434-9.

28. Ibrahim MA, Neo J, Esguerra RJ, Fawzy AS. Characterization of antibacterial and adhesion properties of chitosan-modified glass ionomer cement. J Biomater Appl 2015;30:409-19.

29. Carvalho M, Stamford T. Chitosan as an oral antimicrobial agent.J. of Com. Current Res. and Tech. Adv. 2011:542-4.

30. Ibrahim MA, Meera Priyadarshini B, Neo J, Fawzy AS. Characterization of chitosan/TiO2 nano-powder modified glass-ionomer cement for restorative dental applications. J Esthetic Restor Dent. 2017;29: 146-5. 